\title{
Experimental And Analytical Investigations on RC Short Columns Strengthened by Ferrocement Jacketing And Aramid Fibre Sheet Wrapping
}

\author{
Nalinaa. $K^{1}$ \\ \{kna.civil@psgtech.ac.in\} \\ ${ }^{1}$ Professor, Department of Civil Engineering, PSG College of Technology \\ Coimbatore-641004, India.
}

\begin{abstract}
Reinforced concrete columns are the main load bearing structural elements in the building. These columns need to be repaired or strengthened due to material deficiencies, design deficiencies, poor construction and quality control. The axial load carrying capacity of RC short columns of Grade M25 and of size $150 \mathrm{~mm}$ x $150 \mathrm{~mm}$ and height $1 \mathrm{~m}$ were determined as per IS 456:2000. Seven RC short columns were cast three columns were strengthened by ferrocement jacketing, two columns were strengthened by aramid fibre sheet wrapping and the remaining two columns were reference columns. In ferrocement jacketing technique, woven wire mesh of size $12 \mathrm{~mm}$ $\mathrm{x} 12 \mathrm{~mm}$ opening and diameter of $0.96 \mathrm{~mm}$ were wrapped around the three columns in two layers and mortar of mix ratio 1:3 with a water cement ratio of 0.45 were applied around the columns to cover the wire mesh for a thickness of $20 \mathrm{~mm}$ from each face of the columns. In the aramid fibre sheet wrapping technique, the RC columns were wrapped by a single layer of aramid fibresheet using epoxy resin. All the RC short columns hinged at both ends were tested under axial compression in a loading frame of capacity $1200 \mathrm{kN}$ using a hydraulic jack of capacity $1000 \mathrm{kN}$. Two LVDT's were placed - one perpendicular to the base plate to measure the longitudinal displacement and the other perpendicular to the face of the column to measure the lateral displacement of the columns. The longitudinal and lateral displacements of all $\mathrm{RC}$ short columns for each load increment of $10 \mathrm{kN}$ were observed. The ultimate load carrying capacity of RC short columns strengthened using ferrocement jacketing, aramid fibre sheet wrapping and reference columns were compared. Graphs were plotted for axial load vs longitudinaldisplacement and axial load vs lateral displacement. Finite element analysis of reference columns and strengthened columns were carried out using ABAQUS software. Finally, the experimental results of RC short columns were compared with that obtained from finite element analysis using ABAQUS.
\end{abstract}

Keywords: longitudinal, lateral displacements, RC short columns.

\section{Introduction}

A column is generally a compression member supporting beams and slabs in a structural system. A column may be considered to be short when its effective length does not exceed 12 times the least lateral dimension. Short columns fail by crushing of the material. RC columns often require strengthening to increase their capacity to sustain loads. Strengtheningmay be necessary due to change in use that resulted in additional live loads (like change in use of the 
facility from residential to public or storage), deterioration of the load carrying elements, design errors and construction problems during erection. Common methods for strengthening columns include concrete jacketing, fiber reinforced polymer (FRP) jacketing and steel jacketing. All these methods have been shown to effectively increase the axial load capacity of columns.

Many researchers conducted experiments on square columns strengthened by ferrocement jackets and AFRP sheets to study their performance. Abdullah, Katsuki Takiguchi[1] investigated a technique by using ferrocement jacket for seismic strengthening of RC columns and compared with different strengthening methods. Three methods of strengthening were studied, including steel jacket, carbon fibre sheet, and ferrocement jacket. The results of this investigation indicated that strengthening of a square reinforced concrete column with ferrocement jacket was considered to be successful than the other two methods.

Robert Ravi. S, Prince Arulraj.G[3]conducted experiments on three RC beam-column joints. The column has an overall length of $1500 \mathrm{~mm}$ with a cross section of $200 \mathrm{~mm}$ x 200 $\mathrm{mm}$. The beam has a cantilevered portion with a length of 600 mmand has a dimension of 200 $\mathrm{mm}$ x $200 \mathrm{~mm}$. The specimen C1 has sheets of GFRP asinner layer and AFRP sheet in outer layer. Likewise the specimen $\mathrm{C} 2$ has sheets of AFRP as inner layer and GFRP as outer layer. With the use of hybrid GFRP-AFRP sheet retrofitting technique, the load carrying capacity of the reinforced concrete beam-column joint specimen was found to be $18.3 \%$ more than the control specimens.

Mohammad TaghiKazemi, Reza Morshed [2] investigated a ferrocement jacket reinforced with expanded steel meshes and used to retrofit shear deficient concrete columns. Based on the test results, both circular and square ferrocement jacket enhanced the shear strength and ductility of small-scale square columns.

\section{Material Properties And Mix Design}

\subsection{Cement}

In this study, Ordinary Portland Cement (OPC) of 53 Grade was used. Table1 shows the properties of cement.

Table 1 Properties of Cement

\begin{tabular}{|l|l|}
\hline Tests & Results \\
\hline Specific Gravity & 3.15 \\
\hline Consistency & $33 \%$ \\
\hline Fineness & $1 \%$ \\
\hline Initial Setting Time & $190 \mathrm{~min}$ \\
\hline Final Setting Time & $440 \mathrm{~min}$ \\
\hline
\end{tabular}

\subsection{Fine Aggregates}

The fine aggregates passing through $4.75 \mathrm{~mm}$ IS sieve and retained on 75 micron IS Sieve was taken for the study. Table 2 shows The propertiesof fine aggregates.

Table 2 Properties of Fine Aggregates

\begin{tabular}{|l|l|}
\hline Tests & Results \\
\hline Specific Gravity & $\mathbf{2 . 7 6}$ \\
\hline $\begin{array}{c}\text { Particle size } \\
\text { Distribution }\end{array}$ & Grading zone \\
\hline
\end{tabular}




\subsection{Coarse Aggregates}

\begin{tabular}{|c|c|}
\hline $\begin{array}{c}\text { Free Moisture } \\
\text { Content }\end{array}$ & $\mathbf{0 . 8 7 \%}$ \\
\hline Water Absorption & $\mathbf{1 . 4 \%}$ \\
\hline
\end{tabular}

The coarse aggregates of maximum size $20 \mathrm{~mm}$ was taken for the study. The properties of coarse aggregates are given in Table 3.

Table 3 Properties of Coarse Aggregates

\begin{tabular}{|l|l|}
\hline Tests & Results \\
\hline Specific Gravity & $\mathbf{2 . 8 7}$ \\
\hline Free Moisture Content & $\mathbf{0 . 3 \%}$ \\
\hline Water Absorption & $\mathbf{1 . 3 2} \%$ \\
\hline $\begin{array}{c}\text { Particle Size } \\
\text { Distribution }\end{array}$ & Well graded \\
\hline
\end{tabular}

\subsection{Reinforcement Steel}

High Yield Strength Deformed Bars of Grade Fe 415 are used for the study. Longitudinal bars are of $12 \mathrm{~mm}$ diameter and ties are of $6 \mathrm{~mm}$ diameter.

\subsection{Mix Design}

Concrete mix of Grade M25 was designed as per IS 10262:2009. The obtained mix proportions per $\mathrm{m}^{3}$ of concrete are shown in Table 4 . The mix ratio is $1: 2.14: 3.78: 0.5$.

Table 4 Quantity of Materials

\begin{tabular}{|l|l|}
\hline Materials & Quantity \\
\hline Cement & 350 \\
\hline Fine Aggregates & 750.03 \\
\hline Coarse & 1325 \\
\hline Water & 175 \\
\hline
\end{tabular}

\section{Column Details}

The cross section of the RC short column was chosen as $150 \mathrm{~mm} \times 150 \mathrm{~mm}$ and height 1 $\mathrm{m} .12 \mathrm{~mm}$ diameterbars are used aslongitudinal bars and $6 \mathrm{~mm}$ diameter bars are used as ties with a spacing of $100 \mathrm{~mm} \mathrm{c} / \mathrm{c}$. The description of RC short columns is shown in Table 5. The cross section and reinforcement details of RC column are shown in Figures 1and 2 respectively.

Table 5 Description ofRC Short Columns

\begin{tabular}{|l|l|l|}
\hline S.No. & Symbol & Description \\
\hline 1 & REC 1,2 & Reference Column \\
\hline 2 & SCFJ & $\begin{array}{l}\text { Strengthened Column by } \\
\text { Ferrocement Jacketing }\end{array}$ \\
\hline 3 & SCAF 1,2 & $\begin{array}{l}\text { Strengthened Column by } \\
\text { Aramid fibre sheet wrapping }\end{array}$ \\
\hline
\end{tabular}




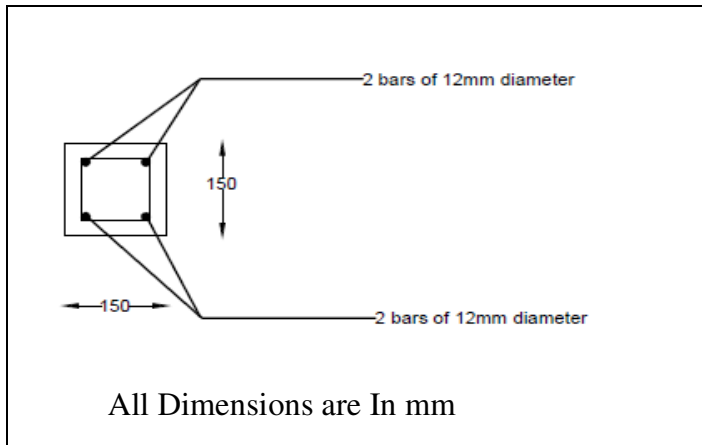

Figure 1:Cross SectionDetails of RCShort Column

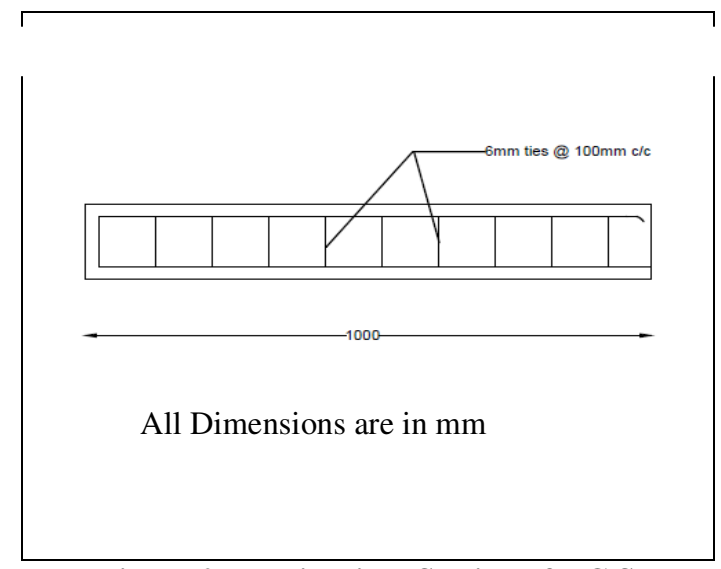

Figure 2:Longitudinal Section of RC Short Column

Axial load carrying capacity of column as per IS 456:2000,

$$
\begin{array}{cl}
\mathrm{P}_{\mathrm{u}} & =0.4 \mathrm{f}_{\mathrm{ck}} \mathrm{A}_{\mathrm{c}}+0.67 \mathrm{f}_{\mathrm{y}} \mathrm{A}_{\mathrm{sc}} \\
\text { where } & \mathrm{A}_{\mathrm{c}} \quad=22047.84 \mathrm{~mm}^{2} \\
\mathrm{~A}_{\mathrm{sc}} & =452.16 \mathrm{~mm}^{2} \\
\mathrm{f}_{\mathrm{ck}} & =25 \mathrm{~N} / \mathrm{mm}^{2} \\
\mathrm{f}_{\mathrm{y}} & =415 \mathrm{~N} / \mathrm{mm}^{2} \\
\mathrm{P}_{\mathrm{u}}=(0.4 \times 2 & 25 \times 22047.84)+(0.67 \times 415 \times 452.16) \\
& =346.2 \mathrm{kN} .
\end{array}
$$

\section{Strengthening Of RC Short Columns}

\subsection{Ferrocement jacketing $[1,2,4]$}

Properties of Materials 
TheWoven Wire Meshused in the jackets had square openings of size $12 \mathrm{~mm}$ x $12 \mathrm{~mm}$ and wire diameter of $0.96 \mathrm{~mm}$. The average yield strength, the average ultimate tensile strength and the average modulus of elasticity of woven wire mesh are $385 \mathrm{MPa}, \quad 524 \mathrm{MPa}$ and 106 MPa respectively.

\section{Fabrication}

Two layers of woven wire mesh is provided in lateral directions.Mortar is filled for a thickness of $20 \mathrm{~mm}$ at all four sides of the short RC columns.Infill mortar is made with watercement ratio of 0.45 and cement sand ratio of 1 : 3 . The $\mathrm{RC}$ short column strengthened by ferrocement jacketing is shown in Figure 3.

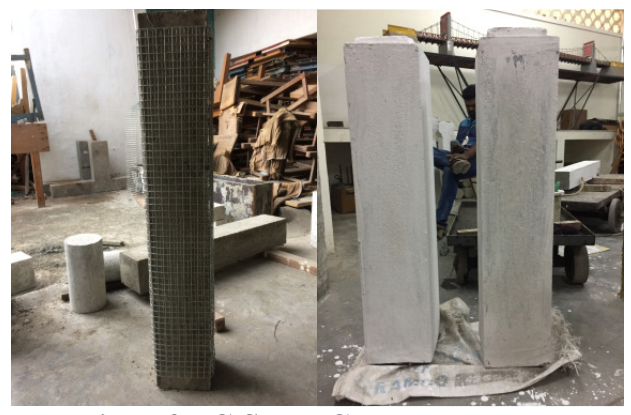

Figure 3: Strengthening of RC Short Columns by Ferrocement Jacketing 4.2 Aramid Fibre Sheet Wrapping

Fabrication

Prior to the application of the epoxy coat to the RC short columns, the concrete surface was cleaned from dust. The aramid fibre sheet which is available in $1000 \mathrm{~mm}$ width is wrapped directly on the fresh epoxy coat on RC columns. The column is wrapped by single layer of AFRP sheet. The epoxy resin is mixed in the ratio of 1:4 (one part of hardener and four parts of base).Figure 4 shows the RC short column strengthened by AFRP wrapping.

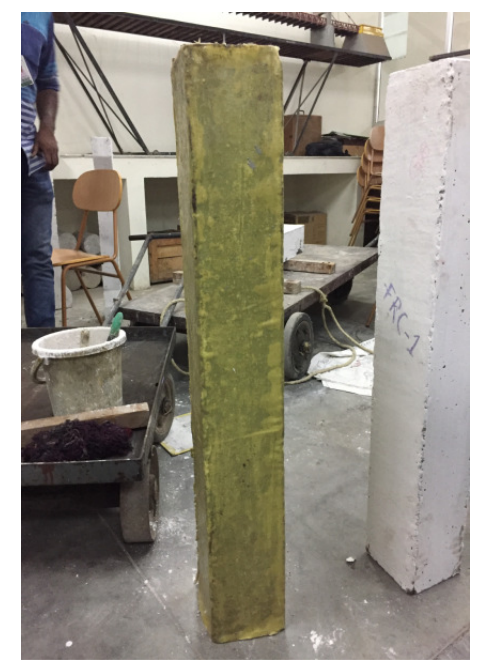


Figure 4: Strengthening of RC Short Columns by Aramid Fibre Sheet Wrapping

\section{Experimental Setup}

All the RC columns were tested under axial compression in a loading frame of capacity $1200 \mathrm{kN}$ using a hydraulic jack of capacity $1000 \mathrm{kN}$. The RC columns were placed vertically in the loading frame and are hinged at both ends. Two LVDT's were placed - one perpendicular to the base plate to measure the longitudinal displacement and the other perpendicular to the face of the column to measure the lateral displacement of the columns. The longitudinal and lateral displacements of all RC short columns for each load increment of $10 \mathrm{kN}$ were observed. The experimental setup is shown in Figure 5.

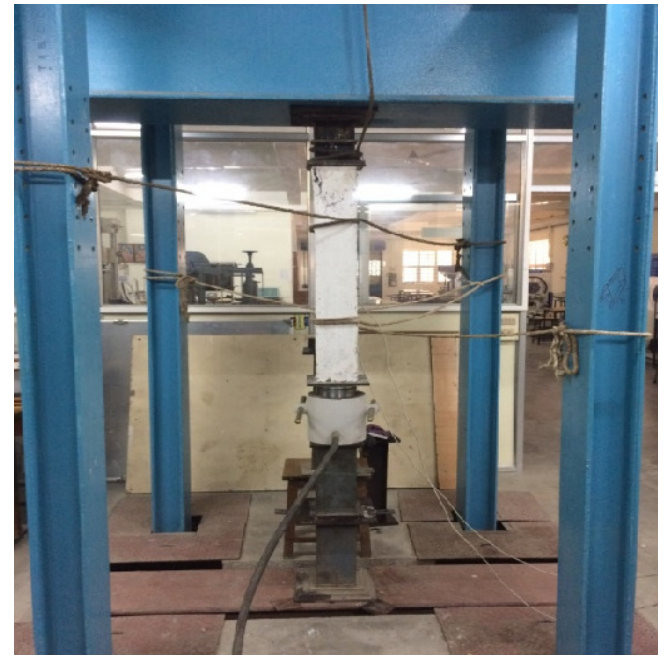

Figure 5:Experimental Setup

\section{Results And Discussions}

\subsection{Ferrocement Jacketing}

From the experimental investigations, the load carrying capacities and the deformations of the columns were observed. The columns REC, SCFJ 1, SCFJ 2, and SCFJ 3 fail at $375 \mathrm{kN}, 670 \mathrm{kN}, 690 \mathrm{kN}$ and $660 \mathrm{kN}$ loads respectively. The above result shows that the column SCFJ 2 carries high axial load of $690 \mathrm{kN}$ The load carrying capacity of reference column and the columns strengthened by ferrocement jacketing is shown in Table 6.

Table 6 Load Carrying Capacity of RC Short Columns

\begin{tabular}{|l|l|l|}
\hline S.No. & Column & Ultimate Load $(\mathbf{k N})$ \\
\hline 1 & REC & 375 \\
\hline
\end{tabular}




\begin{tabular}{|l|l|l|}
\hline 2 & SCFJ 1 & 670 \\
\hline 3 & SCFJ 2 & 690 \\
\hline 4 & SCFJ 3 & 660 \\
\hline
\end{tabular}

The load vs longitudinal deflection of the columns REC, SCFJ 1, SCFJ 2, and SCFJ 3 are shown in Figure 6.

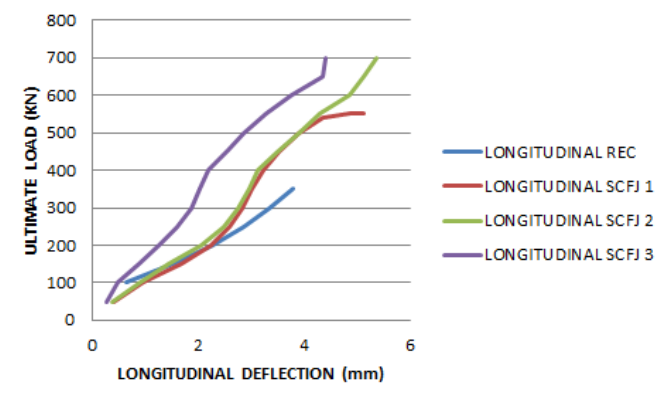

Figure 6:Ultimate Load vs Longitudinal Deflection in REC and SCFJ Columns

The load vs lateral deflection of the columns REC, SCFJ 1, SCFJ 2, and SCFJ 3 are shown are is shown in Figure 7.

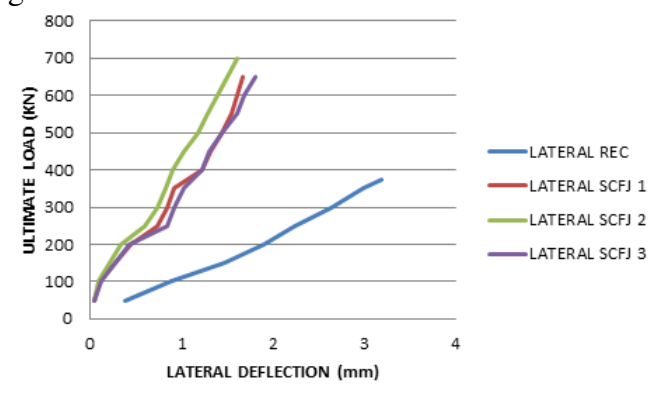

Figure 7:Ultimate Load vs Lateral Deflection in REC and SCFJ Columns

The failure patterns of RC short columns strengthened by ferrocement jacketing and reference columns are shown in Figures 8 and 9 respectively. 

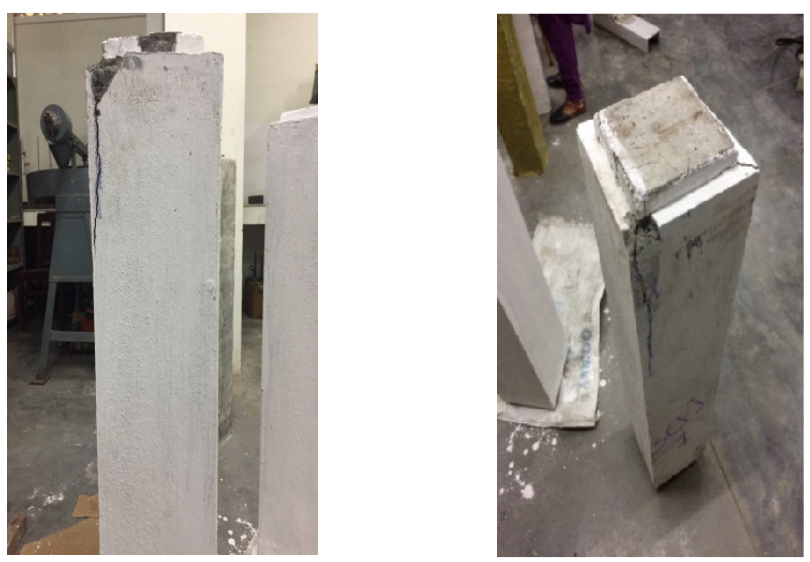

Figure 8: Failure Patterns of RC Short Columns Strengthened by Ferrocement Jacketing
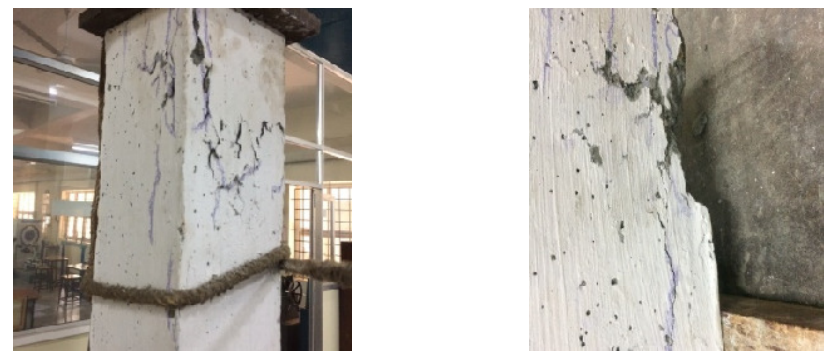

Figure 9: Failure Patterns of Reference RC Short Columns

6.2 Aramid Fibre Sheet Wrapping

From the experimental investigations, the load carrying capacities and the deformations of the columns were observed. The columns REC, SCAF 1 and SCAF 2 failed at 390kN, 550kN and $580 \mathrm{kN}$ respectively The load carrying capacity of reference column and the columns strengthened by ferrocement jacketing is shown in Table 7.

Table 7 Load Carrying Capacity of RC Short Columns

\begin{tabular}{|l|l|l|}
\hline S.No. & Column & Ultimate Load (kN) \\
\hline 1 & REC & 390 \\
\hline 2 & SCAF 1 & 550 \\
\hline 3 & SCAF 2 & 580 \\
\hline
\end{tabular}

The load vs longitudinal deflection of REC, SCAF 1 and SCAF 2 are shown in Figure 10. 


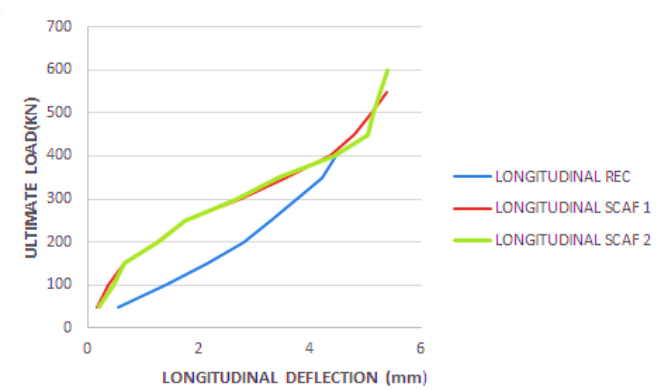

Figure 10:Load vs Longitudinal Deflection in REC and SCAF Columns

The load vs lateral deflection REC, SCAF 1 and SCAF 2 are shown are is shown in Figure 11.

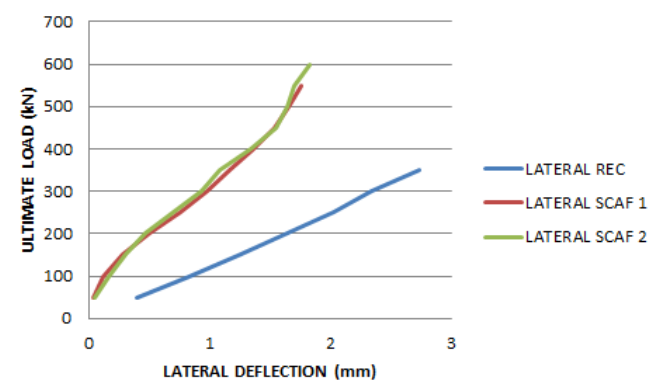

Figure 11: Load Vs Lateral Deflectionin REC and SCAF Columns

The failure patterns of RC short columns strengthened by aramid fibre sheet wrapping is shown in Figure 12.
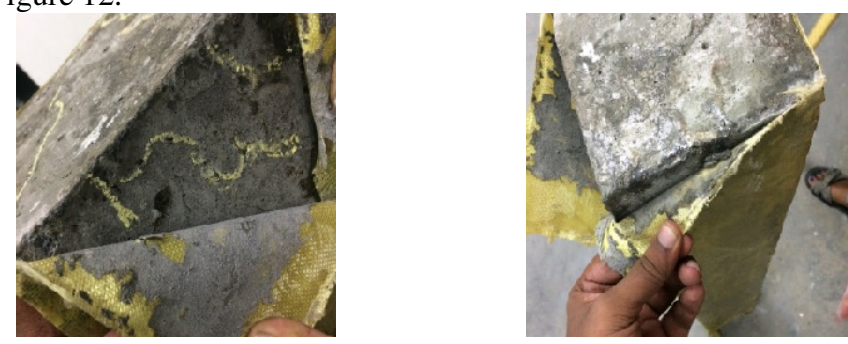

Figure 12: Failure Patterns of RC Short Columns Strengthened by AFRP sheets

\section{Comparison Of Experimental Results}

The load carrying capacities of RC short reference columns, strengthened columns with ferrocement jacketing and aramid fibre sheet wrapping were compared and are shown in Table 8. 
Table 8 Comparison of Load Carrying Capacity

\begin{tabular}{|l|l|l|l|}
\hline S.No. & Column & $\begin{array}{l}\text { Ultimate } \\
\text { Load }(\mathbf{k N})\end{array}$ & $\begin{array}{l}\text { Increase in } \\
\text { Load }(\%)\end{array}$ \\
\hline 1 & REC & 382.5 & - \\
\hline 2 & SCFJ & 673.33 & 76.03 \\
\hline 3 & SCAF & 565 & 47.7 \\
\hline
\end{tabular}

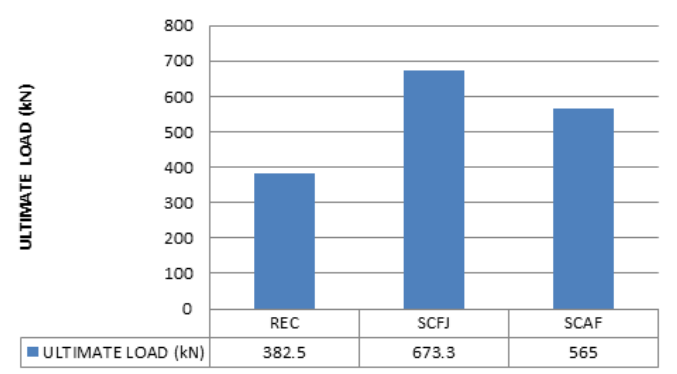

Figure 13: Comparison of Load Carrying Capacity of REC, SCFJ and SCAF

\section{ANALYTICAL STUDY}

Columns

The behaviour of RC reference column and strengthened columns by aramid fibre sheet wrapping were studied analytically using ABAQUS software. Concrete damaged plasticity (CDP) model is used to define the concrete properties. 8 noded brick element is used for concrete element and 3 noded beam element is used for steel element.Table 9shows the plasticity properties of concrete.

Table 9 CDP Model Properties of Concre
\begin{tabular}{|l|l|l|}
\hline 1 & Dilation angle & 38 \\
\hline 2 & Eccentricity & 1 \\
\hline 3 & K & 0.6667 \\
\hline 4 & fb0/fc0 & 1.12 \\
\hline 5 & Viscosity parameter & 0 \\
\hline
\end{tabular}

\section{Embedded Region}

Reinforcement in concrete structures is typically provided by rebar. Normally the rebars are defined as one-dimensional wire truss elements and the reinforcement can be defined in ABAQUS using a single wire.

\subsection{Modeling of Short Reference Columns}

\section{Boundary conditions}

The reference columns were modeled as being vertical, with one side having a fixed-end condition and the other experiencing the applied load.Figure 14 shows the modeling of RC column and reinforcement details 


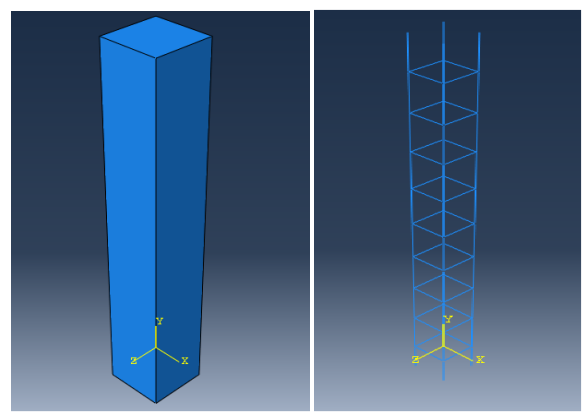

Figure 14: Modeling of RC Short Reference Column and Reinforcement Details Meshing of Reference Columns

The size of mesh used in Finite Element Method (FEM) can affect the results. The mesh size adopted for this study is $50 \mathrm{~mm}$. Figure 15 shows the meshing and the deflected shape of the reference column.

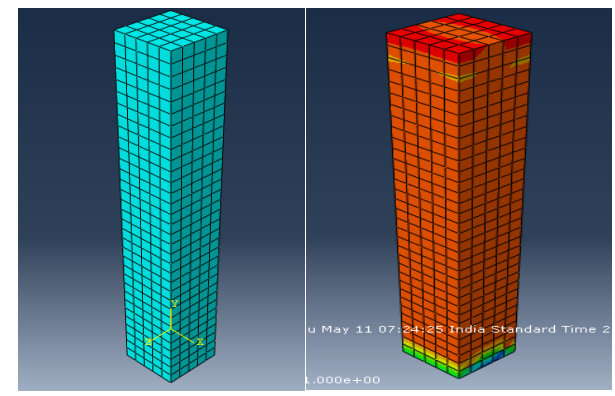

Figure 15: Meshing and Defelected Shape of Short Reference Column

From the analytical study, the ultimate load at which the reference column failed is $354 \mathrm{kN}$ with a maximum longitudinal deflection of $4.17 \mathrm{~mm}$. Figure 16 shows the ultimate load vs longitudinal deflection of the reference column using ABAQUS.

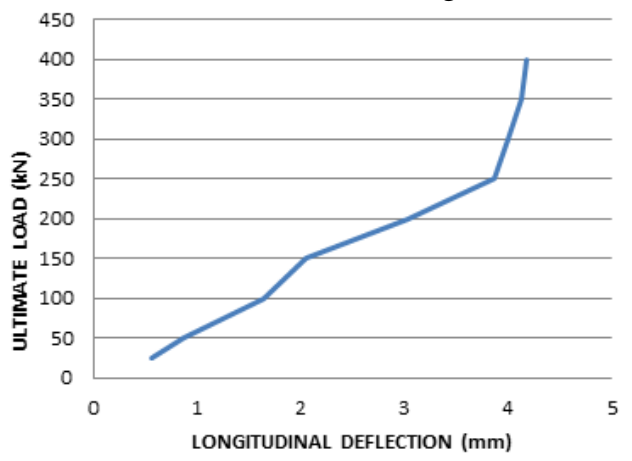

Figure 16:Ultimate Load vs Longitudinal Deflection of Short Reference Column

8.2 Modelingof RC Short Columns Strengthened by Aramid Fibre Sheet Wrapping 
The modeling of the strengthened RC short column by aramid fibre sheet wrapping is shown in the Figure 17.

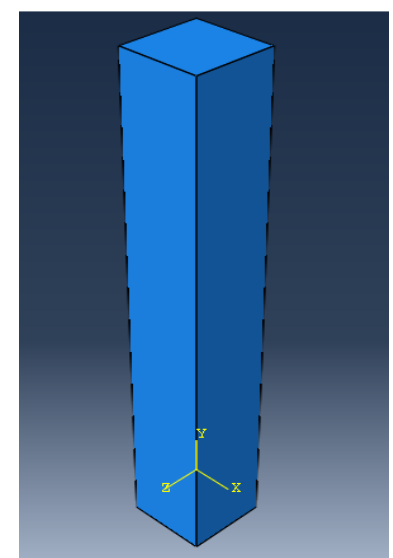

Figure 17: Modeling of RC Short Column Strengthened by AFRP Sheets

Analysis of Strengthened Columns by AFRP Sheets

The mesh size used in Finite Element Method (FEM) can affect the results. The mesh size adopted for this study is $50 \mathrm{~mm}$. Figure 18 shows the meshing and the deflected shape of the strengthened column by AFRP sheets.

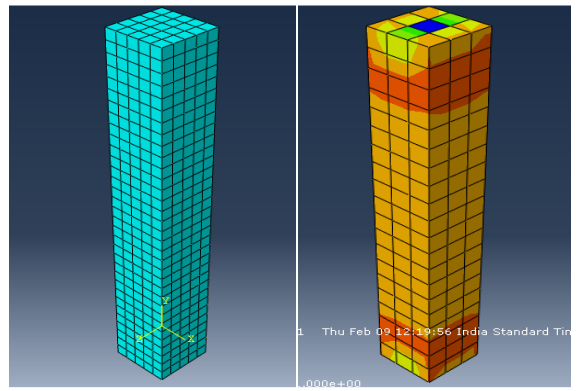

Figure 18: Meshing and Deflected Pattern of RC Short Column Strengthened by AFRP Sheets

From the analytical study, the ultimate load at which the column strengthened by AFRP sheets failed is $537 \mathrm{kN}$ with a maximum longitudinal deflection of $4.41 \mathrm{~mm}$. Figure 19 shows theultimate load vs longitudinal deflection of the strengthened column using ABAQUS. 


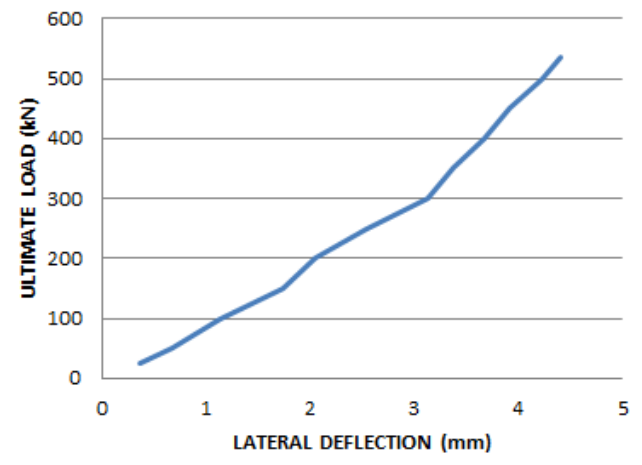

Figure 19:Ultimate Load vs Longitudinal Deflection of RC Short Column Strengthened by AFRP Sheets

8.3 Comparison of Analytical Results

The ultimateload and the longitudinal deflection of the reference column and column strengthened by AFRP sheets are shown in Table 10.

Table 10 Load Carrying Capacity of RC Short Columns Using ABAQUS

\begin{tabular}{|l|l|l|l|}
\hline S.No. & Column & $\begin{array}{l}\text { Ultimate } \\
\text { Load }(\mathbf{k N})\end{array}$ & $\begin{array}{l}\text { Longitudinal } \\
\text { Deflection }(\mathbf{m m})\end{array}$ \\
\hline 1 & REC & 354 & 4.17 \\
\hline 2 & SCAF & 537 & 4.41 \\
\hline
\end{tabular}

\section{Comparisons Of Experimental And Analytical Results}

The comparison of load carrying capacities of reference column andRC short columns strengthened by aramid fibre sheet wrapping byexperimental and analytical study are shown in Table 11 and Figure 20 respectively.

Table 11 Comparisons of Experimental and Analytical Results

\begin{tabular}{|l|l|l|l|}
\hline S.No. & Columns & $\begin{array}{l}\text { Experimental } \\
\text { Study } \\
\text { Ultimate } \\
\text { Load(kN) }\end{array}$ & $\begin{array}{l}\text { Analytical } \\
\text { Study } \\
\text { Ultimate } \\
\text { Load (kN) }\end{array}$ \\
\hline 1 & REC & 382.5 & 354 \\
\hline 2 & SCAF & 565 & 537 \\
\hline
\end{tabular}




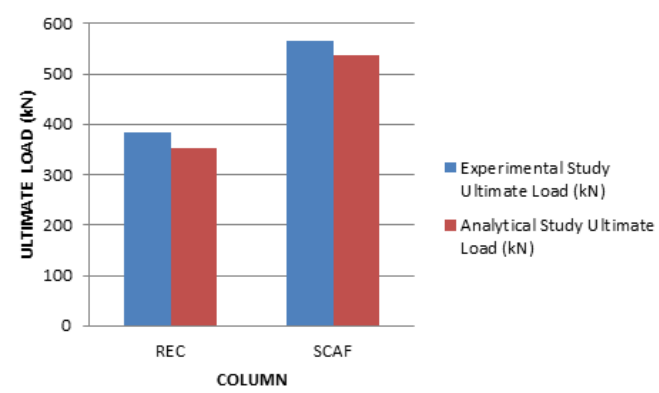

Figure 20: Comparisons of Experimental and Analytical Results of Reference and Strengthened Columns by AFRP Sheets

\section{CONCLUSIONS}

From the experimental and analytical test results on RC short columns and strengthened columns, the following conclusions were drawn.

- Load carrying capacity of RC short columns increases considerably for the twotechniques experimentally.

- The increase in load carrying capacity of RC short columns strengthened by ferrocement jacketing technique is $76.03 \%$ higher than the reference column.

- Increase in cross-sectional area is high in RC short column strengthened by ferrocement jacketing when compared with the columns strengthened by AFRP sheets.

- The columns strengthened by ferrocement jacketing and AFRP sheets showed higher resistance in longitudinal deflection when compared with the reference column.

- $\quad$ RC short column strengthened by AFRP sheets showed an increase in ultimate load of $51.69 \%$ with respect to the reference column based on the analytical study.

\section{ACKNOWLEDGEMENT}

The authors wish to express their sincere gratitude to the Principal and theHead of the Department of Civil Engineering, PSG College of Technology, Coimbatore for providing the necessary facilities to carry out the work reported in this paper.

\section{References}

[1] Abdullah, Katsuki Takiguchi, "An investigation into the behavior and strength of reinforced concrete columns strengthened with ferrocement jackets", Cement \& Concrete Composites, December 2001, pp. 233-242

[2] Mohammad Taghi Kazemi , Reza Morshed, "Seismic shear strengthening of R/C columns with ferrocement jacket”, Cement \& Concrete Composites 27 (2005) 834-842. 
[3] Robert Ravi. S., Prince Arulraj. G, "Experimental Investigation on Behavior of Reinforced Concrete Beam Column Joints Retrofitted with GFRP-AFRP Hybrid Wrapping", International Journal of Civil and Structural Engineering Volume 1, No 2, 2010.

[4] Arvindan Sivasuriyan, D.S. Vijayan, Wojciech Górski, Magdalena Daria Vaverková, Eugeniusz Koda, "Practical Implementation of Structural Health Monitoring in Multi-Story Buildings", Buildings 2021, 11, 263. https://doi.org/10.3390/buildings11060263.

[5] A. Sivasuriyan, D.S.Vijayan et al., "Development of Smart Sensing Technology Approaches in Structural Health Monitoring of Bridge Structures," Adv. Mater. Sci. Eng., vol. 2021, pp. 1-14, 2021, doi: 10.1155/2021/2615029.

[6] V. Gokulnath, D. S. Vijayan, P. Kathirvel, et al., Behaviour of retrofitted beams using natural fibers, Materials Today: Proceedings, https://doi.org/10.1016/j.matpr.2020.06.505

[7] ACI 549R-97 "State-of-the-Art Report on Ferrocement" Reported by ACI Committee 549.

[8] D. S. Vijayan, A. Mohan, J. J. Daniel, V. Gokulnath, B. Saravanan, and P. D. Kumar, "Experimental Investigation on the Ecofriendly External Wrapping of Glass Fiber Reinforced Polymer in Concrete Columns," vol. 2021, 2021.

[9] IS 10262:2009 "Concrete Mix Proportioning - Guideline".

[10] IS 383:1970 "Specification for Coarse and Fine Aggregates from Natural Sources for Concrete".

[11] IS 456:2000 "Plain And Reinforced Concrete - Code Of Practice". 